\title{
Identification of type-specific and cross-reactive neutralizing conformational epitopes on the major capsid protein of human papillomavirus type 31
}

\author{
M. J. J. Fleury ${ }^{1}$, A. Touzé ${ }^{1}$, E. Alvarez ${ }^{1}$, G. Carpentier ${ }^{1}$, C. Clavel ${ }^{2}$, \\ J.-F. Vautherot ${ }^{3}$, and P. Coursaget ${ }^{1}$ \\ ${ }^{1}$ INSERM U618, Université François Rabelais, Tours, France \\ ${ }^{2}$ Hôpital Maison Blanche, Laboratoire Pol Bouin, Reims, France \\ ${ }^{3}$ INRA UR086 BASE, Nouzilly, France
}

Received July 25, 2005; accepted January 25, 2006

Published online March 3, 2006 (C) Springer-Verlag 2006

\begin{abstract}
Summary. The majority of the neutralizing epitopes of papillomaviruses (PV) are conformation-specific and have not been fully characterised. Studies have, to date, been limited to a few HPV types only. We analysed the epitopes on the major capsid protein (L1) of Human papillomavirus (HPV) type 31 using monoclonal antibodies (MAbs) generated against HPV-31 virus-like particles (VLPs). The type-specific MAbs against HPV-31 were all found to be neutralizing and recognized conformation-dependent epitopes. Two other MAbs directed against a conformational epitope were found to be cross-reactive with other HPV types, and one of them was found to be cross-neutralizing. Cross-reactive antibodies were further investigated using wild-type HPV-16 L1 VLPs and two mutants. The results obtained suggested the existence of a cross-neutralizing conformational epitope at the $\mathrm{N}$-terminal part of the FG loop of the major capsid protein, and the other four cross-reactive MAbs recognized epitopes also located at the $\mathrm{N}$-terminal part of the FG loop.
\end{abstract}

\section{Introduction}

Papillomaviruses are small non-enveloped viruses with $\mathrm{T}=7$ icosahedral symmetry. The viral genome is approximately an $8-\mathrm{kb}$ double-stranded DNA genome encapsidated in a structure consisting of 72 capsomers composed of L1. There is also a minor capsid protein involved in the capsid structure; its exact interaction and location in relation to L1 have not been fully characterised; however, it is proposed that the ratio of L1 to L2 is 30:1 [20]. Immunization with self-assembled VLPs made up of L1 or L1 and L2 induces neutralizing antibodies 
that confer type-specific and long-lasting protection in 3 different animal models of papillomavirus infection [2, 21, 34]. In recent years, considerable progress has been made towards the development of prophylactic human papillomavirus (HPV) vaccines to prevent genital HPV infections [17, 45], and evidence of clinical protection has recently been demonstrated [16, 22]. However, no evidence has been observed that this vaccine elicits cross-protection against other HPV types [22]. The HPV vaccines currently under development contain VLPs of types 16 and 18, the two types most frequently associated with cervical neoplasia [28, 40]. Human papillomavirus types $31,33,39,45,52$, and 58 are the other most frequently detected genotypes in cervical cancer patients after HPV-16 and HPV18 [28]. The inclusion of the corresponding VLPs in the composition of HPV vaccines has therefore to be considered. Both linear and conformational epitopes have been identified on the surface of HPV L1 VLPs [9, 10, 18, 39, 41, 44]. It is now well established that conformational epitopes are responsible for neutralizing antibody production [7, 14, 21, 42, 43]. Since neutralization epitopes of HPVs are conformation-dependent, their amino-acid composition and surface localization have not been fully characterized, and studies have been mainly limited to types 6, 11 and 16.

Anti-HPV monoclonal antibodies have been generated against the L1 protein of different human papillomavirus types, and they have been used to map the neutralization epitopes for types 6, 11, 16, and 31 [4, 24-26, 43]. All conformationdependent monoclonal antibody epitopes identified to date are type-specific and have been found to reside on the VLP surface within hypervariable loops, with the exception of the H16.U4 MAb, which was recently demonstrated to bind the C-terminal arm of HPV-16 L1 between residues 427 and 445 [4]. L1 binding sites of neutralizing monoclonal antibodies raised against L1 VLPs include residues within the DE loop for type $11[24,25]$, residues within $\mathrm{BC}$ and $\mathrm{EF}$ loops for type 6 [27], and residues within the FG loop for type 16 [30, 32, 43]. Only one MAb (H31.A6) has been produced for HPV-31 [9]. This antibody is neutralizing [12] and recognizes a conformation-dependent epitope located on the EF loop [4]. Since HPV-31 is the fourth-most prevalent HPV associated with cervical cancer, we generated both HPV-31 murine MAbs and HPV VLPs, and used them to characterize the antigenic structure of its capsid protein.

\section{Materials and methods}

\section{Generation and purification of HPV VLPs}

HPV VLPs were produced in $S f 21$ insect cells using recombinant baculoviruses encoding the L1 gene of HPV-31, and HPV-16, -18, -31 and $-58 \mathrm{~L} 1$ and L2 genes [13, 36]. In addition, two HPV-16 L1 mutants with a hepatitis B core (HBc) 78-83 encoding sequence within the FG loop inserted at position 266/267 (L1-HBc 266/267) and 283/284 (L1-HBc 283/284) [32] were used in order to locate the cross-reactive conformational epitope. $S f 21$ cells maintained in Grace's insect medium (Invitrogen, Cergy Pontoise, France) supplemented with 10\% fetal calf serum (FCS; Invitrogen) were infected with the 7 respective recombinant baculovirus constructs and incubated at $27^{\circ} \mathrm{C}$. Three days post infection, cells were harvested, and VLPs 
were purified as previously described $[13,36]$. Briefly, cells were resuspended in phosphatebuffered saline (PBS) containing Nonidet P40 (0.5\%), pepstatin A, and leupeptin $(1 \mu \mathrm{g} / \mathrm{ml}$ each, Sigma Aldrich, Saint Quentin Fallavier, France), and allowed to stand for $30 \mathrm{~min}$ at $4{ }^{\circ} \mathrm{C}$. Cellular lysates were then centrifuged and nuclear pellets were resuspended in ice-cold PBS containing pepstatin A and leupeptin and then sonicated. Samples were then loaded on a $\mathrm{CsCl}$ gradient and centrifuged to equilibrium (Beckman SW28, 27,000 rpm, 22 h, $4^{\circ} \mathrm{C}$ ). $\mathrm{CsCl}$ gradient fractions were analysed by refractometry for the correct $\mathrm{CsCl}$ density and the presence of $\mathrm{L} 1$ proteins by electrophoresis in $10 \%$ sodium dodecyl sulfate-polyacrylamide gel (SDS-PAGE) with Coomassie blue staining. Positive fractions were pooled, diluted in PBS, and pelleted by ultracentrifugation (Beckman SW 28, 28,000 rpm, $3 \mathrm{~h}, 4^{\circ} \mathrm{C}$ ). VLPs were then resuspended in $0.15 \mathrm{M} \mathrm{NaCl}$ and sonicated by one $5 \mathrm{~s}$ burst at $60 \%$ maximum power. Total protein content was determined using the MicroBCA kit (Pierce, Ozyme, France). The selfassembly of the different HPV-L1 into VLPs was checked by electron microscopy. For this purpose, VLP preparations were applied to carbon-coated grids, negatively stained with $1.5 \%$ uranyl acetate, and observed at $\times 50,000$ nominal magnification with a JEOL 1010 electron microscope.

\section{Generation of HPV monoclonal antibodies}

Six- to eight-week-old female Balb/C mice (IFFA Credo, St. Germain l'Arbresle, France) were immunized by intrapodal injection with purified HPV-31 L1 or HPV-31 L1/L2 VLPs (50 $\mu \mathrm{g})$ emulsified in Quil A $(50 \mu \mathrm{g})$, conducted as previously described with minor modifications [35]. After 12 days, each mouse was boosted with the same preparation. Three days thereafter, mice were sacrificed and popliteal lymph nodes were collected. Lymphocytes were collected by perfusing the lymph node with RPMI 1640-Glutamax medium (Invitrogen). Cells were washed once in RPMI and centrifuged at $300 \mathrm{~g}$ for $5 \mathrm{~min}$ and mixed with Sp2/O myeloma cells at a ratio of 1:5. The cells were then collected by centrifugation at $300 \mathrm{~g}$ for $5 \mathrm{~min}$ and fusions were performed as previously described [37]. Hybridoma culture supernatants were screened for antibody reactivity to both intact and denatured L1 and L1/L2 HPV-31 VLPs. The subsequent steps of subcloning and production of ascites fluid were performed by standard procedures. Subclones were isotyped using the mouse MAb isotyping kit according to the recommended procedure (Sigma-Aldrich). For preparation of ascites, $500 \mu \mathrm{l}$ of tetramethyl penta-decan (Sigma-Aldrich) were injected into the peritoneal cavity of 6 to 8 -week-old female Balb/C mice, and two weeks later, $10^{6}$ hybridoma cells diluted in $500 \mu \mathrm{l}$ of RPMI 1640 glutamax were injected into peritoneal cavities. Ascites fluids were centrifuged at $5000 \mathrm{~g}$ for $5 \mathrm{~min}$ at $4{ }^{\circ} \mathrm{C}$ and then stored at $-20^{\circ} \mathrm{C}$ before use. MAb CamVir- 1 was purchased from Pharmingen (BD Biosciences, Le-Pont-de-Claix, France), and H16.V5 [9] was the kind gifts of N. D. Christensen (The Milton S. Hershey Medical Center, Hershey, PA, USA).

\section{Detection of anti-L1 and anti-L2 antibodies}

Microplates (Maxisorp, Nunc) were coated with $200 \mathrm{ng}$ per well of native or denatured VLPs and incubated at $4{ }^{\circ} \mathrm{C}$ overnight. VLPs were dissociated by treatment with $0.1 \mathrm{M}$ carbonate buffer (pH 10.6) and $0.01 \mathrm{M}$ dithiotreitol (DTT) in PBS for $30 \mathrm{~min}$ at $37^{\circ} \mathrm{C}$. After two washes with PBS-Tween $20(0.1 \%)$, wells were blocked with PBS supplemented with $1 \%$ FCS for $1 \mathrm{~h}$ at $37^{\circ} \mathrm{C}$. Duplicate wells (two tests and one control) were incubated with hybridoma culture supernatant diluted $1 / 3$ in dilution buffer (PBS 5X, 1\% Tween, 10\% FCS) for $1 \mathrm{~h}$ at $37^{\circ} \mathrm{C}$. The plates were washed four times and probed with peroxidase-conjugated goat antimouse Ig Fc (Sigma-Aldrich; 1:5,000 dilution) for $1 \mathrm{~h}$ at $37^{\circ} \mathrm{C}$. After four washes, $100 \mu \mathrm{l}$ of a solution containing $0.4 \mathrm{mg} / \mathrm{ml}$ o-phenylene-diamine and $0.03 \%$ hydrogen peroxide in $25 \mathrm{mM}$ 
sodium citrate and $50 \mathrm{mM} \mathrm{Na} 2 \mathrm{HPO}_{4}$ was added. The reaction was stopped after 30 min with $100 \mu 14 \mathrm{~N} \mathrm{H}_{2} \mathrm{SO}_{4}$ and absorbance was read at $490 \mathrm{~nm}$. A positive result was scored when the difference in OD between test and control wells was greater than 0.20. Endpoint titers were calculated as the last of serial threefold dilutions to yield a positive result. The data presented are the means of two to three determinations.

\section{Preparation of pseudovirions and infectivity assays}

Neutralization of the HPV-16 and 31 pseudovirions with anti-L1 antibodies and anti-L2 antibodies was investigated by inhibition of gene transfer according to a previously described protocol [1] using L1 or L1/L2 VLPs, respectively. Briefly, $10^{4}$ COS-7 cells, cultured in complete Dulbecco's modified Eagle's medium (Invitrogen, DMEM supplemented with 10\% FCS, $100 \mathrm{IU} / \mathrm{ml}$ penicillin and $100 \mu \mathrm{g} / \mathrm{ml}$ streptomycin) were seeded in 96-well plates and incubated for a day at $37^{\circ} \mathrm{C}$. Thereafter, cells were washed twice with DMEM medium. VLPs were mixed with EcoRI-linearized 7.1-kbp pCMV-Luc plasmid (Clontech, Ozyme, Montigny le Bretonneux, France) coding for luciferase, at a 10:1 weight ratio and incubated at room temperature for $30 \mathrm{~min}$. The quantity of DNA/VLP complexes was adjusted to give a luciferase activity of approximately $1,500 \mathrm{cps}$. Fifty $\mu \mathrm{l}$ of hybridoma supernatants diluted at $1 / 3$ in incomplete DMEM medium was added to pseudovirions and incubated at $37^{\circ} \mathrm{C}$ for $30 \mathrm{~min}$ before addition to the cells. After $3 \mathrm{~h}$ at $37^{\circ} \mathrm{C}$, supernatant was removed and $200 \mu \mathrm{l}$ complete DMEM was added to cells. Cells were then incubated for $48 \mathrm{~h}$ at $37^{\circ} \mathrm{C}$. Luciferase gene expression was measured by luminescence assay (Luciferase reporter gene assay with constant light signal, Roche Molecular Biochemical, Meylan, France). Results were expressed as the percentage of inhibition of luciferase activity. $100 \%$ inhibition corresponded to the luciferase activity obtained with DNA alone, and $0 \%$ inhibition corresponded to the luciferase activity obtained with each of the pseudovirions. Antibodies were considered to be neutralizing for inhibition greater than $80 \%$. The data presented correspond to those obtained for 2 to 3 determinations performed in duplicate. End point titers were calculated as the last serial threefold dilution with inhibition of the luciferase expression.

\section{Epitope mapping using synthetic peptides}

Seventy-one 19-amino-acid peptides with a 12-amino-acid overlap, representing the fulllength amino acid sequence of the HPV-31 L1 [15], were synthesized (N-terminal biotinylated with an SGSG spacer; Pepsets, Mimotopes, Clayton Victoria, Australia) with the exception of the first peptide, which was synthesized as C-terminally biotinylated with the spacer at its C-terminus. Twenty-one 12-amino-acid peptides, with a 9-amino-acid overlap, representing amino acid sequences 198 to 221 (EF loop) and 250 to 306 (FG loop) of the HPV-31 L1 protein, were also synthesized. All of the synthetic peptides were diluted at $20 \mu \mathrm{g} / \mathrm{ml}$ in PBS (pH 7.3) with $0.1 \%$ BSA and added to the wells of a streptavidin-precoated plate (Mimotopes). After $1 \mathrm{~h}$ incubation at $37^{\circ} \mathrm{C}$, and 4 washes with PBS, $0.05 \%$ Tween 20 , the plates were blocked with $0.1 \%$ BSA in PBS for $1 \mathrm{~h}$ at $37^{\circ} \mathrm{C}$. The MAbs diluted $1 / 3$ in dilution buffer were added and allowed to react for $1 \mathrm{~h}$ at $37^{\circ} \mathrm{C}$. After 4 washes with PBS-Tween 20, a peroxidase conjugated goat antibody against murine IgG (Sigma-Aldrich) diluted 1:5000 in dilution buffer was added, and the plates were incubated for $1 \mathrm{~h}$ at $37^{\circ} \mathrm{C}$. The plates were washed 4 times and the peroxidase activity was measured as above.

\section{Detection of MAbs reactivities against WT and mutant VLPS}

Reactivity of MAbs was also investigated against wild-type and mutant VLPs. For this purpose, ascite fluids were diluted at 1/250 and tested simultaneously against the three VLPs according to the procedure described above for the detection of L1 antibodies. The results 
are the means of 3 or 4 determinations, and the results observed with mutant 283/284 were adjusted according to the results observed with CamVir-1 MAb.

\section{Results}

\section{Reactivity of the HPV-31 MAbs produced}

After subcloning of the HPV-31 reactive hybridomas, eighteen subclones were selected for further study. Only one such clone was produced from a mouse immunized with L1 VLPs and the 17 others from mice immunized with L1/L2 VLPs. The antibodies produced by these 18 subclones were investigated for crossreactivity using L1/L2 VLPs for types 16, 18, and 58 and for neutralization using HPV-31 L1 pseudovirions as described previously [1]. MAbs were tested by ELISA using intact and denatured HPV-31 VLPs composed of L1 alone or L1/L2 proteins (Table 1). None of the monoclonal antibodies identified reacted only with L1/L2 VLPs, indicating that all were directed against L1 epitopes and none was directed at an L2 epitope. To investigate the possibility that some hybridomas produced L2 antibodies but were not detected by ELISA using L1/L2 VLPs, we tested 37 anti-HPV-31 L1-negative hybridomas for the production of neutralizing antibodies using HPV-31 L1/L2 pseudovirions. No neutralizing effect was observed for any of the hybridomas investigated (data not shown). In order to detect cross-reactivity, HPV-31 L1 monoclonal antibodies were also investigated for their binding to intact and denatured VLPs for types 16, 18, and 58. Fifteen MAbs were found to bind to surface conformational epitopes, as they bound to intact but not to denaturated VLPs. One MAb (H31.D24) was reactive to a linear epitope present on the surface of the VLPs as it bound to intact and denaturated VLPs, and two MAbs (H31.B5 and H31.E22) recognized a buried linear epitope as they bound strongly to denaturated VLPs and only weakly to native VLPs. Two of the 15 MAbs that recognized a conformational epitope were cross-reactive with L1 VLPs for types 16 and 18, and one of them was also reactive with HPV-58 VLPs. All three MAbs (H31.B5, H31.E22, and H31.D24) recognized a linear epitope and were cross-reactive to HPV-16 VLPs, whereas two (H31.D24 and H31.B5) were cross-reactive with HPV-18 and -58 VLPs.

\section{Neutralizing activity of HPV-31 L1 monoclonal antibodies}

Neutralizing activity of the MAbs was investigated using HPV-16 and HPV-31 pseudovirions (Table 2). Neutralization of HPV-31 pseudovirions was not observed with the 3 MAbs directed against a linear epitope (H31.D24, H31.B5, and H31.E22). All 13 MAbs directed against a type-specific conformational epitope were found to be neutralizing (a reduction greater than $80 \%$ of the gene transfer observed with the pseudovirions). H31.F7 and H31.C19 were found to have conformational epitopes. H31.F7 had cross-reactivity to HPV types 16, 18, and 58, whereas H31.C19 has cross-reactivity to HPV-16 and 18. In addition, H31.F7 MAb was found to be HPV-31- and 16-neutralizing. High neutralization activity 


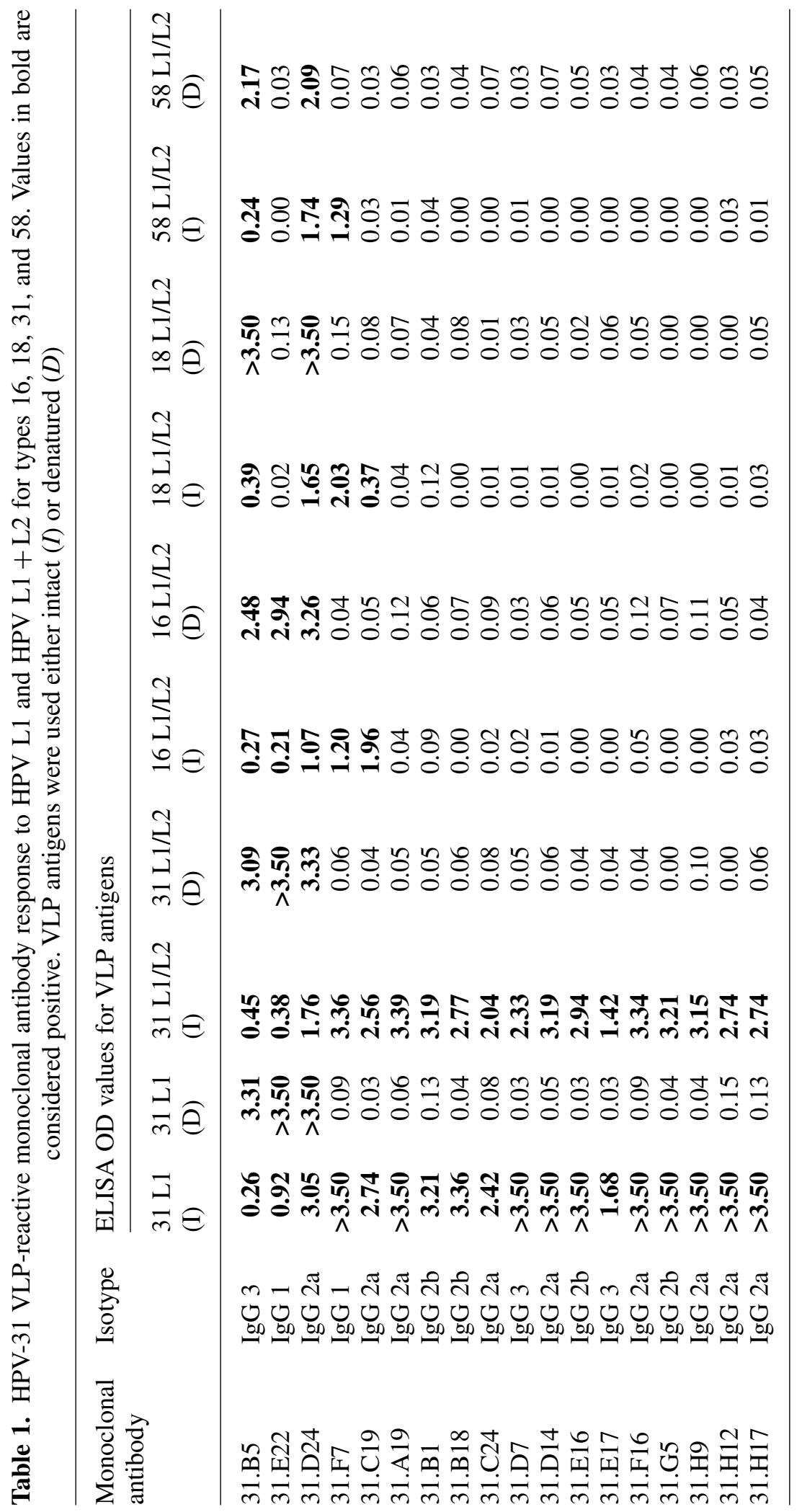


Table 2. Characteristics of the 18 HPV-31 MAbs produced: antibody titers, crossreactivities, and in vitro neutralization of HPV-16 and HPV-31 pseudovirions

\begin{tabular}{|c|c|c|c|c|c|}
\hline \multirow{2}{*}{$\begin{array}{l}\text { Monoclonal } \\
\text { antibody }\end{array}$} & \multirow{2}{*}{$\begin{array}{l}\text { Epitope } \\
\text { recognized }^{\mathrm{a}}\end{array}$} & \multirow{2}{*}{$\begin{array}{l}\text { Antibody } \\
\text { titer }\end{array}$} & \multirow{2}{*}{$\begin{array}{l}\text { Cross-reactivity } \\
\text { for HPV types }\end{array}$} & \multicolumn{2}{|c|}{ Neutralizing titers for: } \\
\hline & & & & HPV-16 & HPV-31 \\
\hline 31.B5 & $\mathrm{L}$ & 30 & $16,18,58$ & $<3$ & $<3$ \\
\hline 31.E22 & $\mathrm{L}$ & 30 & 16 & $<3$ & $<3$ \\
\hline 31.D24 & $\mathrm{L}$ & 7,290 & $16,18,58$ & $<3$ & $<3$ \\
\hline 31.F7 & $\mathrm{C}$ & 7,290 & $16,18,58$ & 3 & 10 \\
\hline 31.C19 & $\mathrm{C}$ & 2,430 & 16,18 & $<3$ & $<3$ \\
\hline 31.A19 & $\mathrm{C}$ & 7,290 & - & $<3$ & 10 \\
\hline 31.B1 & $\mathrm{C}$ & 7,290 & - & $<3$ & 90 \\
\hline 31.B18 & $\mathrm{C}$ & 90 & - & $<3$ & 30 \\
\hline 31.C24 & $\mathrm{C}$ & 2,430 & - & $<3$ & 10 \\
\hline 31.D7 & $\mathrm{C}$ & 810 & - & $<3$ & 3 \\
\hline 31.D14 & $\mathrm{C}$ & 7,300 & - & $<3$ & 90 \\
\hline 31.E16 & $\mathrm{C}$ & 2,430 & - & $<3$ & 30 \\
\hline 31.E17 & $\mathrm{C}$ & 30 & - & $<3$ & 10 \\
\hline 31.F16 & $\mathrm{C}$ & 810 & - & $<3$ & 90 \\
\hline 31.G5 & $\mathrm{C}$ & 7,290 & - & $<3$ & 90 \\
\hline 31.H9 & $\mathrm{C}$ & 2,430 & - & $<3$ & 90 \\
\hline 31.H12 & $\mathrm{C}$ & 7,290 & - & $<3$ & 810 \\
\hline 31.H17 & $\mathrm{C}$ & 2,430 & - & $<3$ & 90 \\
\hline
\end{tabular}

${ }^{\mathrm{a}} C$, conformational; $L$, linear

was observed for H31.B18, H31.E17, H31.F16, H31H9, and H31.H12, since the ratio between their neutralizing and ELISA titers is higher than 0.1 .

\section{Epitope mapping of MAbs using overlapping HPV-31 L1 peptides}

The HPV-31 L1 linear epitopes were further localized by reacting MAbs in an ELISA with a set of 71 overlapping peptides spanning the entire 504 residues of the L1 protein of HPV-31. HPV-16 CamVir 1 MAb and three MAbs reacting only with native VLPs were also investigated. As predicted, no reactivity to the peptides was observed for the three MAbs (H31.F7, H31.C19, H31.F16) that were reactive with conformational epitopes (data not shown). The MAb H31.D24 recognized linear sequences that lie between amino acids 267 to 285 (TVGESVPTDLYIKGS GSTA) and 275 to 292 (TDLYIKGSGSTATLANSTY) of the HPV-31 L1 protein. CamVir-1 recognized sequences 190 to 208 (ELKNSVIQDGDMVDTGFGA) and 197 to 215 (QDGDMVDTGFGAMDFTALQ). None of these peptides were reactive with H31.B5 and H31.E22 MAbs. In addition, these 3 HPV-31 MAbs were tested against 12 mer synthetic peptides spanning the FG loop of HPV$31 \mathrm{~L} 1$, and CamVir-1 antibody against $12 \mathrm{mer}$ synthetic peptides spanning the amino acid sequence 198 to 221 of the HPV-31 L1. From the results obtained, the SVPTDLYIK sequence (amino acids 271 to 279) was recognized by MAb 
H31.D24, and CamVir-1 recognized the MVDTGFGAM sequence (amino acids 201 to 209). None of the 12 mer synthetic peptides investigated were reactive with H31.B5 or H31.E22 MAbs. The failure of H31.B5 and H31.E22 to react with any peptides could be related to the low reactivity of these antibodies since their ELISA titer was only $1 / 30$.

\section{Characterization of linear and conformational cross-reacting epitopes using mutants of HPV-16 L1 VLPS}

The fact that $5 \mathrm{HPV}-31$ MAbs cross-reacted with HPV-16 VLPs prompted us to compare the binding of these antibodies to wild-type (wt) HPV-16 VLPs to the binding to VLPs previously generated with HPV-16 L1 protein mutants, corresponding to the insertion of a 6-amino-acid $\mathrm{HBc}$ sequence within the FG loop, at positions $266 / 267$ and $283 / 284$, respectively [32]. It is clearly evident

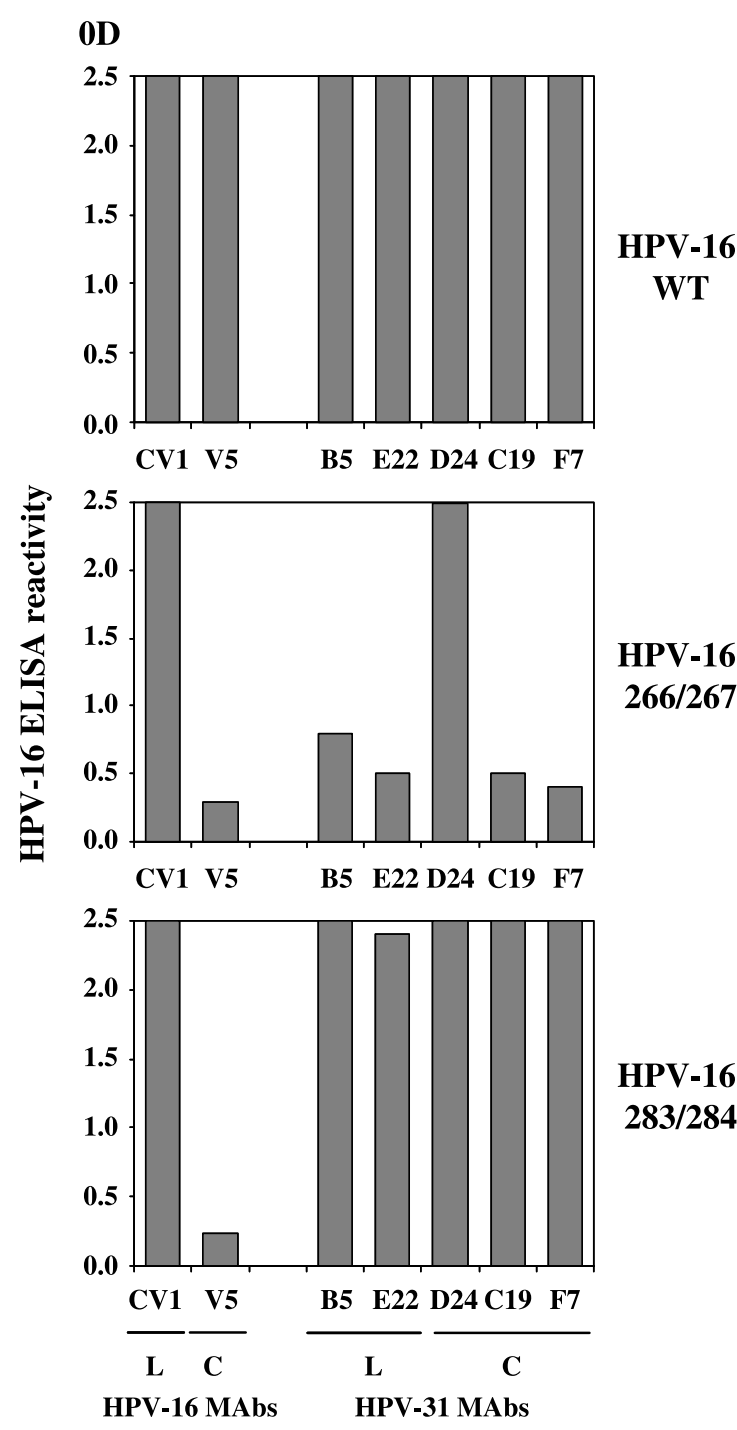

Fig. 1. ELISA reactivity of 5 crossreactive HPV-31 MAbs with wildtype and FG-mutant HPV-16 VLPs. $L=$ linear, $C=$ conformational 
that H31.D24 is not affected by the insertion of the HBc sequence in the FG loop (Fig. 1). However, MAbs H31.F7, H31.C19, H31.B5, and H31.E22 had reduced binding to L1-HBc 266/267. As previously observed [32], MAb H16.V5 used as control did not bind efficiently to either mutant compared to wild-type L1 VLPs, and CamVir-1 antibody directed against a linear epitope bound similarly to wild-type and mutant VLPs.

\section{Discussion}

We generated a panel of 18 MAbs reactive to HPV-31 VLPs and screened these MAbs for cross-reactivity to HPV-16,-18, and -58 by ELISA and for neutralization with HPV-16 and HPV-31 pseudovirions. Thirteen MAbs were type-specific and all of them recognized conformation-dependent epitopes since reactivity was lost by capsid disruption. Five MAbs (H31.B5, H31.E22, H31.D24, H31.F7, and H31.C19) were cross-reactive, three of these (H31.B5, H31.E22, and H31.D24) recognized linear epitopes and two (H31.F7 and H31.C19) recognized conformational epitopes. These findings suggest that the VLP preparation used for immunization and hybridoma screening contained mostly non-denatured VLPs since only two out of 18 MAbs recognized a buried epitope. In addition, it must be noted that no MAb directed against the L2 protein was produced. This could be due to the low proportion of L2 proteins in the capsid composition [20], which means that only a small proportion of the L2 epitopes are presented at the surface of VLPs $[6,31]$, or to the fact that L1 epitopes are immunodominant. Further, it is possible that the test we used for anti-L2 screening is less sensitive than for L1. To investigate the possibility that the hybridomas produced anti-L2 antibodies that were undetectable by ELISA using L1/L2 VLPs, we tested anti-L1-negative hybridomas for the production of neutralizing antibodies. The absence of neutralization against HPV-31 L1/L2 pseudovirions confirmed that anti-L2 antibodies were not produced. In agreement with previous studies showing that many typespecific conformational MAbs identify virus-neutralizing epitopes [6-10, 12, 29], we observed that HPV-31 type-specific MAbs were all found to be neutralizing and their ELISA reactivity was dependent on the conformation of the capsid. In addition, HPV-31 and HPV-16 neutralizing assays determined that only one of the 5 cross-reactive MAbs was cross-neutralizing with HPV-16 pseudovirions. This MAb (H31.F7) recognized a conformation-dependent epitope. This result is in agreement with the observation of Christensen et al. [10] that some cross-reactive HPV-6 MAbs neutralize HPV-11 virions. The existence of cross-reactive epitopes is correlated with the existence of high levels of cross-reactivity between these types $[12,14]$. The above studies provide further evidence that cross-neutralizing epitopes exist between HPV-16, -31, and 58 [12], as observed for HPV-6 and 11 [10] and types 18 and 45 [14], and suggest that, as observed for the L2 protein $[19,31]$, L1 contains common neutralizing epitopes. However, ongoing clinical trials demonstrate that, although high levels of protection against vaccine types are observed, no evidence of cross-protection has been obtained [3, 22]. This is in agreement with the fact that there is no epidemiological evidence of natural cross-protection between related HPV types [38]. 
Since most HPV neutralization epitopes are conformation-dependent, their surface localization on VLPs have not been fully characterized. Only one HPV-31 MAb had been produced before this study (H31.A6). It was found to recognize an epitope situated on the EF loop [4]. The localization of conformational epitopes was previously obtained by investigation of the reactivity of MAbs to VLPs with insertion of foreign peptides within the different hypervariable loops of the L1 protein [32, 33] or hybrid papillomavirus VLPs [4, 11]. Similarly, we examined whether peptide insertion in the FG hypervariable region of HPV-16 L1 would disrupt HPV-16 cross-reacting MAb-binding to VLPs by ELISA. Since five HPV-31 MAbs cross-react with HPV-16, we investigated their reactivity with wild-type HPV-16 L1 VLPs and two mutants previously created by insertion of a short heterologous sequence within the FG loop of HPV-16 L1 protein at positions 266/267 and 283/284 [30]. In contrast to the binding observed with the $\mathrm{H} 16$.V5 MAb, the binding of which is affected by insertion at both positions [30], MAb binding to VLPs was affected by insertion at position $266 / 267$, but not by insertion at position 283/284 for H31.B5, H31.E22, H31.C9, and H31.F7. This result suggests the existence of cross-reactive conformational and linear epitopes at the N-terminal part of the FG loop. However, insertions can have both local and global structural effects on the surface loops of VLPs such that loss of binding is not a pure indicator of a specific conformational epitope site. In addition, we identified a linear cross-reactive epitope, SVPTDLYIK, as part of the H31.D24 epitope. This sequence is well conserved among high risk HPVs. This sequence is part of the ENVPDDLYIKGSGS sequence described as corresponding to H16.J4 [9] and 8C4, 5A4, and 1D6 MAbs described by Cason et al. [5] and part of the GTVGENVPDDLYIK sequence recognized by MC1-10 and MC-34 described by Kulski et al. [23]. This position is in agreement with the fact that the reactivity of this MAb was not affected by insertion of a foreign epitope at positions 266/267 and 283/284. This epitope is localized at the N-terminus of the FG loop and is surface-exposed at the top but also at the side of the capsomer.

In conclusion, the mapping and characterization of the epitopes of high-risk HPVs could contribute to understanding the immunopathobiology of HPV infections and could provide valuable information for the engineering of HPV vaccines. These MAbs will be important tools in attempts to monitor immunity developed in HPV vaccine recipients and to further characterize the protective epitopes on HPV-31 virions. HPV-31 mutants are therefore currently under development in order to investigate whether type-specific neutralizing MAbs are directed against the FG loop or not, as observed with HPV-16 [14, 30, 32].

\section{Acknowledgments}

We thank N. D. Christensen (University of Pennsylvania, Hershey) for H16.V5 MAb, P. Y. Sizaret for electron microscopy (Laboratory of Electron microscopy, University of Tours) and the staff of INRA UR086 BASE for assisting with the MAb work. MF, EA and GC were supported by grants from the Ministère de la Recherche, INSERM/Région Centre and Vaincre la Mucoviscidose, respectively. This study was funded by grants to PC from the Ligue Contre le Cancer (Comité d'Indre et Loire) and Vaincre la Mucoviscidose. 


\section{References}

1. Bousarghin L, Touzé A, Combita AL, El Mehdaoui S, Sizaret PY, Bravo MM, Coursaget P (2002) Detection of neutralizing antibodies against human papillomaviruses (HPV) by inhibition of gene transfer mediated by HPV pseudovirions. J Clin Microbiol 40: 926-932

2. Breitburd F, Kirnbauer R, Hubbert NL, Nonnenmacher B, Trin-Dinh-Desmarquet C, Orth G, Schiller JT, Lowy DR (1995) Immunization with viruslike particles from cottontail rabbit papillomavirus (CRPV) can protect against experimental CRPV infection. J Virol 69: 3959-3963

3. Brown DR, Fife KH, Wheeler CM, Koutsky LA, Lupinacci LM, Railkar R, Suhr G, Barr E, Dicello A, Li W, Smith JF, Tadesse A, Jansen KU (2004) Early assessment of the efficacy of a human papillomavirus type $16 \mathrm{~L} 1$ virus-like particle vaccine. Vaccine 22: 2936-2942

4. Carter JJ, Wipf GC, Benki SF, Christensen ND, Galloway DA (2003) Identification of a human papillomavirus type 16-specific epitope on the C-terminal arm of the major capsid protein L1. J Virol 77: 11625-11632

5. Cason J, Patel D, Naylor J, Lunney D, Shepherd PS, Best JM, McCance DJ (1989) Identification of immunogenic regions of the major coat protein of human papillomavirus type 16 that contain type-restricted epitopes. J Gen Virol 70: 2973-2987

6. Christensen ND, Kreider JW, Cladel NM, Patrick SD, Welsh PA (1990) Monoclonal antibody-mediated neutralization of infectious human papillomavirus type 11. J Virol 64: $5678-5681$

7. Christensen ND, Kirnbauer R, Schiller JT, Ghim SJ, Schlegel R, Jenson AB, Kreider JW (1994a) Human papillomavirus types 6 and 11 have antigenically distinct strongly immunogenic conformationally dependent neutralizing epitopes. Virology 205: 329-335

8. Christensen ND, Hopfl R, DiAngelo SL, Cladel NM, Patrick SD, Welsh PA, Budgeon LR, Reed CA, Kreider JW (1994b) Assembled baculovirus-expressed human papillomavirus type $11 \mathrm{~L} 1$ capsid protein virus-like particles are recognized by neutralizing monoclonal antibodies and induce high titres of neutralizing antibodies. J Gen Virol 75: 2271-2276

9. Christensen ND, Dillner J, Eklund C, Carter JJ, Wipf GC, Reed CA, Cladel NM, Galloway DA (1996) Surface conformational and linear epitopes on HPV-16 and HPV-18 L1 viruslike particles as defined by monoclonal antibodies. Virology 223: 174-184

10. Christensen ND, Reed CA, Cladel NM, Hall K, Leiserowitz GS (1996) Monoclonal antibodies to HPV-6 L1 virus-like particles identify conformational and linear neutralizing epitopes on HPV-11 in addition to type-specific epitopes on HPV-6. Virology 224: 477-486

11. Christensen ND, Cladel NM, Reed CA, Budgeon LR, Embers ME, Skulsky DM, McClements WL, Ludmerer SW, Jansen KU (2001) Hybrid papillomavirus L1 molecules assemble into virus-like particles that reconstitute conformational epitopes and induce neutralizing antibodies to distinct HPV types. Virology 291: 324-334

12. Combita AL, Touzé A, Bousarghin L, Christensen ND, Coursaget P (2002) Identification of two cross-neutralizing linear epitopes within the L1 major capsid protein of human papillomavirus. J Virol 76: 6480-6486

13. Combita AL, Bravo MM, Touzé A, Orozco O, Coursaget P (2002) Serologic response to human oncogenic papillomavirus types $16,18,31,33,39,58$ and 59 virus-like particles in colombian women with invasive cervical cancer. Int J Cancer 97: 796-803

14. Giroglou T, Sapp M, Lane C, Fligge C, Christensen ND, Streek RE, Sapp M (2001) Immunological analyses of human papillomavirus capsids. Vaccine 19: 1783-1793

15. Goldborough MD, DiSelvestre D, Temple GF, Lorincz AT (1989) Nucleotide sequence of human papillomavirus type 31: A cervical neoplasia associated virus. Virology 171: 306-311 
16. Harper DM, Franco EL, Wheeler C, Ferris DG, Jenkins D, Schuind A, Zahaf T, Innis B, Naud P, De Carvalho NS, Roteli-Martins CM, Teixeira J, Blatter MM, Korn AP, Quint W, Dubin G, GlaxoSmithKline HPV Vaccine Study Group (2004) Efficacy of a bivalent L1 virus-like particle vaccine in prevention of infection with human papillomavirus types 16 and 18 in young women: a randomised controlled trial. Lancet 364: 1757-1765

17. Harro CD, Pang YY, Roden RB, Hildesheim A, Wang Z, Reynolds MJ, Mast TC, Robinson R, Murphy BR, Karron RA, Dillner J, Schiller JT, Lowy DR (2001) Safety and immunogenicity trial in adult volunteers of a human papillomavirus $16 \mathrm{~L} 1$ virus-like particle vaccine. J Natl Cancer Inst 93: 284-292

18. Heino P, Skyldberg B, Lehtinen M, Rantala I, Hagmar B, Kreider JW, Kirnbauer R, Dillner J (1995) Human papillomavirus type 16 capsids expose multiple type-restricted and type-common antigenic epitopes. J Gen Virol 76: 1141-1153

19. Kawana K, Yoshikawa H, Taketani Y, Yoshiike K, Kanda T (1999) Common neutralization epitope in minor capsid protein L2 of human papillomavirus types 16 and 6. J Virol 73: 6188-6190

20. Kirnbauer R, Taub J, Greenstone H, Roden R, Durst M, Gissmann L, Lowy DR, Schiller JT (1993) Efficient self-assembly of human papillomavirus type 16 L1 and L1-L2 into viruslike particles. J Virol 67: 6929-6936

21. Kirnbauer R, Chandrachud LM, O'Neil BW, Wagner ER, Grindlay GJ, Armstrong A, McGarvie GM, Schiller JT, Lowy DR, Campo MS (1996) Virus-like particles of bovine papillomavirus type 4 in prophylactic and therapeutic immunization. Virology 219: $37-44$

22. Koutsky LA, Ault KA, Wheeler CM, Brown DR, Barr E, Alvarez FB, Chiacchierini LM, Jansen KU (2002) A controlled trial of a human papillomavirus type 16 vaccine. N Engl J Med 347: 1645-1651

23. Kulski JK, Sadleir JW, Kelsall SR, Cicchini MS, Shellam G, Peng SW, Qi YM, Galloway DA, Zhou J, Frazer IH (1998) Type specific and genotype cross reactive B 20 epitopes of the L1 protein of HPV16 defined by a panel of monoclonal antibodies. Virology 243: $275-282$

24. Ludmerer SW, Benincasa D, Mark GE 3rd (1996) Two amino acid residues confer type specificity to a neutralizing, conformationally dependent epitope on human papillomavirus type 11. J Virol 70: 4791-4794

25. Ludmerer SW, Benincasa D, Mark GE 3rd, Christensen ND (1997) A neutralizing epitope of human papillomavirus type 11 is principally described by a continuous set of residues which overlap a distinct linear, surface-exposed epitope. J Virol 71: 3834-3839

26. Ludmerer SW, McClements WL, Wang XM, Ling JC, Jansen KU, Christensen ND (2000) HPV11 mutant virus-like particles elicit immune responses that neutralize virus and delineate a novel neutralizing domain. Virology 266: 237-245

27. McClements WL, Wang XM, Ling JC, Skulsky DM, Christensen ND, Jansen KU, Ludmerer SW (2001) A novel human papillomavirus type 6 neutralizing domain comprising two discrete regions of the major capsid protein L1. Virology 289: 262-268

28. Munoz N, Bosch FX, de Sanjose S, Herrero R, Castellsague X, Shah KV, Snijders PJ, Meijer CJ (2003) Epidemiologic classification of human papillomavirus types associated with cervical cancer. N Engl J Med 348: 518-527

29. Roden RB, Weissinger EM, Henderson DW, Booy F, Kirnbauer R, Mushinski JF, Lowy DR, Schiller JT (1994) Neutralization of bovine papillomavirus by antibodies to L1 and L2 capsid proteins. J Virol 68: 7570-7574

30. Roden RB, Armstrong A, Haderer P, Christensen ND, Hubbert NL, Lowy DR, Schiller JT, Kirnbauer R (1997) Characterization of a human papillomavirus type 16 variant dependent neutralizing epitope. J Virol 71: 6247-6252 
31. Roden RB, Yutzy WH 4th, Fallon R, Inglis S, Lowy DR, Schiller JT (2000) Minor capsid protein of human genital papillomaviruses contains subdominant, cross-neutralizing epitopes. Virology 270: 254-257

32. Sadeyen JR, Tourne S, Shkreli M, Sizaret PY, Coursaget P (2003) Insertion of a foreign sequence on capsid surface loops of human papillomavirus type 16 virus-like particles reduced their immunogenicity and delineates a conformational neutralizing epitope. Virology 309: 32-40

33. Slupetzky K, Shafti-Keramat S, Lenz P, Brandt S, Grassauer A, Sara M, Kirnbauer R (2001) Chimeric papillomavirus-like particles expressing a foreign epitope on capsid surface loops. J Gen Virol 82: 2799-2804

34. Suzich JA, Ghim SJ, Palmer-Hill FJ, White WI, Tamura JK, Bell JA, Newsome JA, Jenson AB, Schlegel R (1995) Systemic immunization with papillomavirus L1 protein completely prevents the development of viral mucosal papillomas. Proc Natl Acad Sci USA 92: 11553-11557

35. Thouvenin E, Laurent S, Madelaine MF, Rasschaert D, Vautherot JF, Hewat EA (1997) Bivalent binding of a neutralising antibody to a calicivirus involves the torsional flexibility of the antibody hinge. J Mol Biol 270: 238-246

36. Touzé A, El Mehdaoui S, Sizaret PY, Mougin C, Munoz N, Coursaget P (1998) The L1 major capsid protein of human papillomavirus type 16 variants affects yield of virus-like particles produced in an insect cell expression system. J Clin Microbiol 36: 2046-2051

37. Vautherot JF, Madelaine MF, Boireau P, Laporte J (1992) Bovine coronavirus peplomer glycoproteins: detail antigenic analyses of S1, S2 and HE. J Gen Virol 73: 1725-1737

38. Viscidi RP, Snyder B, Cu-Uvin S, Hogan JW, Clayman B, Klein RS, Sobel J, Shah KV (2005) Human papillomavirus capsid antibody response to natural infection and risk of subsequent HPV infection in HIV-positive and HIV-negative women. Cancer Epidemiol Biomarkers Prev 14: 283-288

39. Volpers C, Sapp M, Snijders PJ, Walboomers JM, Streeck RE (1995) Conformational and linear epitopes on virus-like particles of human papillomavirus type 33 identified by monoclonal antibodies to the minor capsid protein L2. J Gen Virol 76: 2661-2667

40. Walboomers JM, Jacobs MV, Manos MM, Bosch FX, Kummer JA, Shah KV, Snijders PJ, Peto J, Meijer CJ, Munoz N (1999) Human papillomavirus is a necessary cause of invasive cervical cancer worldwide. J Pathol 189: 12-19

41. Wang XM, Cook JC, Lee JC, Jansen KU, Christensen ND, Ludmerer SW, McClements WL (2003) Human papillomavirus type 6 virus-like particles present overlapping yet distinct conformational epitopes. J Gen Virol 84: 1493-1497

42. White WI, Wilson SD, Bonnez W, Rose RC, Koenig S, Suzich JA (1998) In vitro infection and type-restricted antibody-mediated neutralization of authentic human papillomavirus type 16. J Virol 72: 959-964

43. White WI, Wilson SD, Palmer-Hill FJ, Woods RM, Ghim SJ, Hewitt LA, Goldman DM, Burke SJ, Jenson AB, Koenig S, Suzich JA (1999) Characterization of a major neutralizing epitope on human papillomavirus type 16 L1. J Virol 73: 4882-4889

44. Yaegashi N, Jenison SA, Valentine JM, Dunn M, Taichman LB, Baker DA, Galloway DA (1991) Characterization of murine polyclonal antisera and monoclonal antibodies generated against intact and denatured human papillomavirus type 1 virions. J Virol 65: $1578-1583$

45. Zhang LF, Zhou J, Chen S, Cai LL, Bao QY, Zheng FY, Lu JQ, Padmanabha J, Hengst K, Malcolm K, Frazer IH (2000) HPV6b virus like particles are potent immunogens without adjuvant in man. Vaccine 18: 1051-1058

Author's address: P. Coursaget, Faculté des Sciences Pharmaceutiques, 31 avenue Monge, 37200 Tours, France; e-mail: coursaget@univ-tours.fr 